\title{
The Role of Insider Influence in Mutual-to-Stock Conversions
}

\begin{abstract}
Using a sample of 347 demutualizing thrifts from 1991 to 2004, we show that the level of inside participation is not a traditional signal of firm performance. We conclude that unanticipated inside participation reflects the incentives of insiders to reduce the size of the offer to influence the level of expected IPO returns. We find unanticipated inside participation is related to lower offer size and higher initial returns, but we do not find a relationship between inside participation and post-IPO performance.
\end{abstract}




\section{The Role of Insider Influence in Mutual-to-Stock Conversions}

Insiders are widely acknowledged to possess asymmetric information. Previous research suggests that insiders use asymmetric information related to firm value to enhance their personal

trading strategies [Seyhun (1986); Lee (1997); Kahle (2000); Chalmers, Dann, and Harford (2002)]. We analyze thrift conversions to investigate the incentives of insiders who purchase shares when their firms convert from a mutual form of ownership to a stock form of ownership.

Maksimovic and Unal (1993) analyze the influence of inside participation on depositor purchases, management's choice of issue size, and initial returns during mutual-to-stock conversions. They conclude that the interests of insiders and outside investors are aligned in that both groups receive benefits from the initial returns at the time of the offer. They do not find evidence consistent with managers maximizing the issue size at the expense of outside investors in order to increase the resources under managerial control.

We extend the work of Maksimovic and Unal (1993) by updating the sample period, refining the measure of inside participation, and further exploring the impact of inside participation on the choice of offer size and firm performance following the offer. We argue that when management purchases a larger than anticipated portion of the initial offer, they are communicating their confidence in the expected performance of the offer. We define the proportion of inside participation that is explained by firm characteristics as the anticipated or predicted participation using techniques similar to those in Aggarwal, Prabhala, and Puri (2002) and Barro (1977). Specifically, we posit that unanticipated participation signals management's projection of future performance or their incentive to influence the offer terms in order to enhance their gains at the time of the offer. 
Using a sample of 347 converting thrifts from 1991 to 2004, we find evidence consistent with participating managers enhancing returns at the initial public offer by influencing the size of the offer. We test whether a statistical relationship exists between unanticipated participation and initial returns, offer size, and post-conversion operating performance. The greater the level of unanticipated participation, the higher the initial returns and the lower the offer size; however, no relationship exists between higher levels of participation and long-term operating performance subsequent to conversion. As we demonstrate through a model developed by Masulis (1987), lower offer amounts are expected to result in greater gains at the IPO. We conclude that the level of inside participation is not a traditional signal of firm value; instead, greater than anticipated inside participation reflects incentives of insiders to reduce the size of the offer, resulting in the ability of insiders to capture a greater share of value from the demutualization.

By comparing our sample characteristics to that of Masulis (1987), Maksimovic and Unal (1993), and Colantuoni (1998), we also document changes in the characteristics of demutualizing thrifts. Relative to demutualizations in the 1980's and early 1990's, thrifts in the 1990's are wellcapitalized, sell at higher price-to-book ratios, and have larger first-day returns.

In Section I of this paper we review the demutualization literature and the historical development of thrift demutualizations. Section II outlines our model development and empirical implications. We describe our data in Section III, our empirical results in Section IV, and Section V concludes.

\section{Demutualization Literature and History}

Most mutual thrift institutions originated as local cooperative ventures where members pool their savings to finance home mortgages. Although depositors nominally own their mutual 
thrift, actual ownership rights are limited. For example, depositor claims to earnings are nontransferable and the mutual thrift generally retains its earnings indefinitely. In a standard demutualization, a mutual thrift converts to a stock company as qualified depositors and insiders receive non-transferable rights to buy shares during the stock offer. Following conversion, the new shareholders own the contributed capital plus the equity that accumulated prior to the demutualization.

Kroszner and Strahan (1996) argue that regulators encouraged capital-impaired thrifts to convert to stock organizations in the 1980s to bring private capital into the cash-starved industry. Masulis (1987) finds that mutual thrifts are more likely to convert if they are highly levered and operate in markets that exhibit greater competition and growth. Masulis (1987) reports an average initial one-day return of 5.6\% for conversions from 1983-1987. Maksimovic and Unal (1993) find average initial returns of 5.0\% from 1980 to 1988, and Alli, Yau and Yung (1994) find an average of 7\% from 1983 to 1987.

The motivation and subsequent returns of conversions in the 1990s differ from earlier conversions. Mutual thrifts in this second wave of conversions are well-capitalized with dramatically higher initial returns. Barth, Brumbaugh and Kleidon (1994) report average initial returns of 24\% for 1992 and 29\% for 1993. Cox and Roden (1999) find average one-day adjusted returns of $26.3 \%$ for the period 1993 to 1997.

Mutual thrift managers and directors claim that converting to a publicly traded company strengthens the institution by increasing current capital and improving access to capital markets. Stockholders with vested interest in superior performance improve company performance through increased scrutiny. In addition, the existence of common stock allows the firm to offer 
stock incentives to managers and facilitates consolidations and acquisitions [Watterson and Laufenberg (1990)].

Some industry observers claim mutual thrift IPOs unjustly enrich thrift insiders because the transactions lack the usual tension between buyers and sellers. Because mutual thrifts have no clear residual claimants, no shareholders have incentive to argue for a higher price during the conversion to a stock company. It is well recognized that insiders in the thrift industry have incentives and opportunities to profit from mutual-to-stock conversions [Meredith (1994)]. Mutual insiders, who typically initiate and help set the terms of the IPO, are also eligible to participate in the offer. Insiders work with underwriters and appraisers to set the conversion terms allowing depositors and insiders to capture the accumulated equity value. Any unsubscribed stock is offered to the public. Dunham (1985) finds that insiders purchase 20\% of all conversion shares. Cox and Roden (1999) find that inside participation averaged 10\% during the period $1988-1997$.

\section{Model Development and Hypotheses}

\section{A. Motivation}

In thrift demutualizations the new shareholders contribute proceeds from the offer in order to own all of the pre-existing value as well as the proceeds from the IPO. As a result, in a thrift demutualization, we expect some level of stock appreciation to occur at the time of the initial offer regardless of the level of proceeds. ${ }^{1}$ Insiders are eligible to participate by buying shares at the offer price and they influence the terms of the conversion including the level of proceeds through the choice of offer price and number of shares. Because of these unique

\footnotetext{
${ }^{1}$ Assuming new capital is not invested in negative net present value (NPV) projects where the negative NPV more than offsets the value of the pre-existing capital.
} 
characteristics, traditional IPO underpricing theories such as: asymmetric information [Rock (1986), Beatty and Ritter (1986), Benveniste and Spindt (1989), and Chemmanur (1993)], quality signals [Allen and Fualhaber (1989), Welch (1989), and Garfinkel (1993)], insurance from litigation [Drake and Vetsuypens (1993) and Lowry and Shu (2002)], and price support [Rudd (1993)] may only partially explain underpricing in demutualizing thrifts.

Previous research poses that insiders may act opportunistically during stock offers. Giamarino, Heinkel, and Hollifield (1994) develop a model where insiders have motives to exploit private information in the secondary market while simultaneously issuing new shares in the primary market. Ang and Brau (2002) provide further evidence that insiders act opportunistically in traditional IPOs.

To understand the parameters that affect the terms of a thrift demutualization, we rely on a model developed by Masulis (1987) and extended by Maksimovic and Unal (1993) and Unal (1997). Equation (1) shows that the value of the resulting stock firm $\left(V_{1}\right)$ is equal to the market value of the thrift prior to conversion $\left(V_{0}\right)$, plus the value of the proceeds (PROCEEDS) from the offer, plus the present value of new growth opportunities $(P V G O)$ related to accessing the public capital markets. While investors in the IPO contribute the proceeds, they receive the rights to the total firm value $\left(V_{1}\right)$.

$$
V_{1}=V_{0}+P R O C E E D S+P V G O
$$

The most commonly used valuation metric for depository firms is the price-to-book ratio [Rhoades (1987), Cheng, Gup, and Wall (1989), Rose (1991), and Brewer, Jackson, Jagtiani, and Nguyen (2000)]. At the time of the offer, the price-to-book ratio is equal to

$$
\text { Price-to-book }{ }_{0}=\text { PROCEEDS } /\left(\text { PROCEEDS }+ \text { EQUITY }_{0}\right) \text {, }
$$


where $E Q U I T Y_{0}$ is the book value of equity prior to the offer and PROCEEDS is the offer price multiplied by the shares sold at the time of the offer. In the secondary market, the price-to-book ratio reflects the market value of the firm, incorporating the growth opportunities and the prior equity value.

$$
\text { Price-to-book }{ }_{1}=\left(V_{0}+\text { PROCEEDS }+ \text { PVGO }\right) /\left(\text { PROCEEDS }+ \text { EQUITY }_{0}\right)
$$

The gain from underpricing can be observed through the change in the ratio of the price-to-book ratio in the secondary market (Price-to-book ${ }_{1}$ ) relative to the price-to-book ratio based on the offer price (Price-to-book $_{0}$.

$$
\begin{aligned}
\text { Percent gain from the offer } & =\left(\text { Price-to-book }{ }_{1} / \text { Price-to-book }_{0}\right)-1 \\
& =\left(V_{0}+\text { PVGO }\right) /(\text { PROCEEDS })
\end{aligned}
$$

The initial shareholders invest the proceeds from the offer to receive the full value of the firm. The expected gain from this purchase is equal to the prior market value of the thrift plus the present value of the growth opportunities related to issuing public stock.

Equations (1) through (5) demonstrate that the key determinant of underpricing and price ratios is the proceeds from the conversion. Rewriting equation (5) as $V_{0} / P R O C E E D S+$ PVGO/PROCEEDS, highlights the potential tradeoff between the choice of offer size and the firm's future performance. Minimizing the offer proceeds increases $V_{0} /$ PROCEEDS which reflects insiders and participating depositors capturing a greater proportion of the preexisting value of the mutual thrift. As stated in Maksimovic and Unal (1993, p 1664-1665), "If the mutual thrift has positive equity value but does not have positive NPV growth opportunities the 
management can ensure that initial investors, including themselves, increase the return from investment $\rho$ by minimizing the issue size.”

The unique circumstances of mutual thrift IPOs create incentives for insiders to influence the offer parameters to permit greater inside ownership and allow purchase of the pre-existing thrift value at a low price. Depositors and insiders are given non-transferable rights to participate in the offer. Participating depositors' incentives are aligned with the insiders in that each benefits from a low overall offer price represented by the level of proceeds. Using a simplified example, if the preexisting market value of the mutual thrift equals \$50 million, then proceeds of \$200 million allow participants to buy a \$250 million thrift for \$200 million, resulting in an expected $25 \%$ initial return. A lower amount of proceeds, such as $\$ 100$ million, would result in a 50\% initial return. Given wealth constraints of insiders and participating depositors, a lower level of proceeds allows investors to capture a higher percentage of the offer as well as a higher percentage of the preexisting value. ${ }^{2}$ Non-participating depositors are not explicitly harmed by the offer, but instead suffer an opportunity loss by their choice not to participate.

The second part of equation 5 incorporates the present value of growth opportunities PVGO. If $P V G O$ is a function of PROCEEDS (reflecting positive NPV investment opportunities); then greater PROCEEDS increase the long-run value of the firm and the wealth of participants. To avoid the transaction costs from a secondary offer, it may be "optimal for the thrift to increase the issue size and fully leverage up this additional equity” (Maksimovic and Unal p. 1665). Because thrift insiders have proprietary information regarding the value of $P V G O$, their decision relating to the level of proceeds is particularly interesting. Higher proceeds can

\footnotetext{
${ }^{2}$ The OTS prohibits insiders from borrowing from the thrift to purchase additional shares.
} 
also provide unique benefits to insiders through greater leadership security and perquisite opportunities to manage more assets and personnel.

Maksimovic and Unal (1993) find that higher inside participation in the offer is related to higher levels of issue size, where they define issue size as the offer price divided by the average of the minimum and maximum appraised value of the converting thrift. ${ }^{3}$ They also find that insider participation is positively related to initial IPO returns during the 1980 - 1985 period, but insignificant in the 1986 - 1988 period. They further report that insiders are not motivated by agency cost considerations. However, Maksimovic and Unal conduct their study during the 1980s when the motivation for conversion was typically linked to regulatory concerns about capitalization and initial returns were relatively low (5\%). In our more recent sample initial returns are more than four times as high. Thus, there may be changes in the role insiders play during mutual-to-stock conversions.

It should not be surprising that insiders may favorably influence the terms of the offer. ${ }^{4} \mathrm{~A}$ thrift's conversion offer price and proceeds are the result of a negotiated process between the thrift's management, the underwriter, and the appraiser. Management also influences the choice of both underwriter and appraiser. Central to the appraisal process are a series of regulatory equations, which Unal (1997) shows to be flawed. Also as stated by Unal (1997) management

\footnotetext{
${ }^{3}$ We define issue size as the dollar proceeds raised in the offer. Econometrically, we assume that our control variables (proxied by firm and industry characteristics) provide the best unbiased estimate of the anticipated level of proceeds.

${ }^{4}$ Many other studies already document that managers influence the parameters of their firm's operating performance or reporting strategy to enhance their personal wealth through compensation agreements, dividend policy, stock repurchases, and insider trading [Yermack (1997), Aboody and Kasznik (2000), Karpoff and Lee (1991), Lee (1997), Kahle (2000), Clarke, Dunbar, and Kahle (2001), Lambert, Lanen, and Larcker (1989), and Fenn and Liang (2001)]. Previous studies also find evidence of self-interested managerial actions during changes in organizational structure such as IPOs [Teoh, Welch, and Wong (1998), Field and Karpoff (2002), and Chalmers, Dann, and Harford (2002)].
} 
chooses an offer price that is within 15 percent of this "appraised" value. Regulatory influence from the Office of Thrift Supervision (OTS), personal wealth constraints, and tensions between short-term and long-term objectives, further complicate the process of setting the terms of the offer.

The degree to which management influences the offer size and price is constrained by regulators. Regulators realize that greater capital minimizes the cost of deposit insurance. Also as stated by Henry Gonzales, former House Banking Committee Chairman, regulators must ensure that “insiders and acquirers don't benefit at the expense of the institution and its account holders" [Unal (1997)]. In fact, throughout the 1990s, with various degrees of intensity, the Office of Thrift Supervision (OTS) pressured appraisers and insiders of converting thrifts to increase priceto-book ratios at the time of the offer [Smith and Underwood (1997)].

Ultimately, insiders face two decisions relating to the terms of the offer. Insiders must choose their personal level of financial participation as well as the overall level of proceeds. The level of proceeds results in a price-to-book ratio that cannot fall below the thrift regulators' current acceptable threshold. Initial returns at the time of the offer are a reflection of this decision process. ${ }^{5}$

Using data from 1980 to 1988, Maksimovic and Unal (1993) find average initial returns of 5\%. In our sample of 347 conversions from 1991 to 2004, we find a 20.8\% average initial return. The more recent time period includes the recapitalizations of well- capitalized thrifts with dramatically higher initial returns. The dramatic differences in initial returns, along with changes

\footnotetext{
${ }^{5}$ The level of proceeds reflects the overall price of the thrift. The price per share at the time of the offer is typically set at an arbitrary standard price (i.e. $\$ 8, \$ 10, \$ 12$ ). The number of shares offered is determined by the proceeds divided by the offer price. Hence, insiders have only one degree of freedom in choosing the terms of the offer.
} 
in the regulatory environment, provide motivation to investigate changes in the incentive for thrift insiders to influence the terms of the offer.

\section{B. Hypotheses}

Maksimovic and Unal (1993) use the percent of inside participation in the offer as a measure of asymmetric information. However, subsequent research by Boyle, Carter, and Stover (1998) demonstrates that a significant portion of inside participation is predictable based on publicly available information at the time of the thrift conversion. We use a process similar to Aggarwal, Prabhala, and Puri (2002) and Barro (1977) that differentiates between inside participation determined by public information (anticipated participation) and inside participation determined by asymmetric information (unanticipated participation).

Based on these studies we develop three hypotheses. Our first hypothesis is that the level of unanticipated participation is positively correlated with the first-day IPO returns. A positive relationship between inside ownership and initial returns demonstrates that managerial participation can be viewed as a signal of first-day returns; however, it does not show whether the signal reflects future firm performance or managerial influence on the offer size. In our second and third hypotheses we test whether unanticipated inside ownership is statistically related to the offer size and future performance.

If unanticipated managerial ownership is positively related to initial returns, offer size, and future performance, managerial participation provides a signal of the future performance of the firm. Consistent with traditional theory, managers purchase a larger share of the offer due to asymmetric information concerning future growth opportunities and offer proceeds are increased to take advantage of the positive net present value investments available to the thrift. 
Alternatively, we may find that unanticipated managerial ownership is positively related to initial returns and negatively related to offer size, implying that management decreased the offer size to enhance IPO returns. If we also find a significant negative relationship between unanticipated managerial ownership and future operating performance, we can conclude that insiders reduced offer size at the expense of turning down positive NPV projects due to lack of capital. If there is a significant positive relationship between unanticipated managerial ownership and future performance, we can conclude that insiders reduced offer size to avoid potential overinvestment in negative net present value projects. ${ }^{6}$

\section{Data}

Our sample includes conversions of mutual thrifts from 1991 to 2004. We chose this sample period for two reasons. First, the Federal Deposit Insurance Corporation Improvement Act (FDICIA) of 1991 created a new regulatory regime where unhealthy institutions were closed and healthier institutions began to prosper. Second, our primary data resource, SNL DataSource, only maintains balance sheet and income statement data on firms starting in 1991. We discard observations with missing variables and/or where data between SNL and CRSP had discrepancies that could not be rectified through a proxy statement. SNL DataSource provides details on offer proceeds, price, shares outstanding, price-to-book ratios, and inside participation at the time of the offer. SNL DataSource also provides information on the firm's prior year ROA,

\footnotetext{
${ }^{6}$ Throughout our analysis, we assume that thrifts only issue and purchase new stock if positive NPV projects exist. Therefore, managers invest at least a portion of capital raised in positive NPV projects. We allow for the potential that managers may over-invest through an inverted Ushape relationship between PVGO and the level of proceeds.
} 
core capital ratio, and asset growth. ${ }^{7}$ We also use SNL DataSource to calculate the thrift industry average price-to-book ratio. The final sample consists of 347 thrifts. We winsorize variables at the $5^{\text {th }}$ and the $95^{\text {th }}$ percentile to insure the results are not driven by extreme values. ${ }^{8}$ Table I shows the frequency of demutualizations by year. The numbers range from a low of 2 in 1991 to a high of 61 in $1995 .{ }^{9}$

Table II provides a summary of mean values for selected variables. The average total assets of a demutualizing thrift in our sample is $\$ 285,980,270$ with over three quarters of the converted thrifts trading on a major exchange. Average proceeds at the time of the offer equal $\$ 36,850,470 .{ }^{10}$ The average offer size is very similar to the offer size reported by Maksimovic and Unal (1993). The average one-day return at the time of the offer is $20.8 \%$, compared to a one-day return of 5\% in Maksimovic and Unal's sample. Higher returns may be due to greater capitalization ratios (CORE), defined as core capital divided by risk-adjusted assets proxy for prior conversion value or a healthier industry climate as demonstrated by higher price-to-book

${ }^{7}$ Unlike SNL DataSource, SNL Securities Monthly Market Report does not always include measures of prior year ROA and capital ratios. For these observations we obtained ROA, capital ratios, and asset growth from the company's SEC filings.

${ }^{8}$ Non-winsorized results provide similar conclusions.

${ }^{9}$ Beginning in 1992 some mutual thrifts elected to establish a mutual holding company (MHC) as an alternative means to convert to a stock company. In a MHC conversion, the maximum issue of publicly traded stock is $49.9 \%$, while the majority shares are owned by a newly created holding company that is jointly owned by the thrift depositors. It is possible for a mutual thrift that converted to the MHC form to subsequently convert to a full stock company in a process termed a second-stage conversion. During a second-stage public offer, thrift depositors and insiders again receive non-transferable rights to purchase the company's shares [Luse and Gorman (2005)]. Preliminary analysis shows no difference in insider influence on the offer based on the form of the demutualization. However, because the level of proceeds in a MHC is restricted to less than half of the total stock, we restrict our final analysis to full demutualizations.

${ }^{10}$ SNL includes both employee stock ownership plans (ESOP) and management recognition plans (MRP) in the gross proceeds. During our sample period, most conversions are fully subscribed and underwritten on a best-efforts basis. 
ratios $\left(I N D \_P / B\right)$ that proxy for industry growth opportunities. The offer price-to-book ratio averages $66.6 \%$ while the corresponding average industry price-to-book ratio is $97.7 \%$.

Table III shows correlations between the variables. The largest correlation, not surprisingly, is between assets and proceeds. None of the other correlations between variables appear to raise significant multicollinearity concerns. Actual inside participation is negatively correlated with the level of proceeds and the initial price-to-book ratio. Actual participation is not significantly correlated with initial returns.

\section{Empirical Tests and Results}

Our empirical tests focus on the decisions of thrift insiders who must choose their personal level of financial participation in the offer as well as the overall level of proceeds. In subsections A and B below we develop measures of anticipated and unanticipated inside participation. In subsection $\mathrm{C}$ we relate these measures to the percentage price change at the time of the IPO. In subsection D we investigate the influence of insiders on measures of the offer size. Finally, in subsection E we test for a relationship between inside participation and long-term operating performance.

\section{A. Anticipated Inside Participation}

We use information publicly available at the time of the offer to estimate anticipated inside participation. We use an Ordinary Least Squares (OLS) regression to predict inside participation (INSIDE), that we define as the percent of shares purchased by officers and directors. ${ }^{11}$ Boyle, Carter, and Stover (1998) show inside participation in mutual conversions is inversely related to size. We define size (ASSETS) as the log of the firm's total assets in

\footnotetext{
${ }^{11}$ We also use the log of inside participation and deviations from the maximum purchase. We find similar results with these alternative measures of inside participation.
} 
thousands from the year prior to the demutualization. Loderer and Martin (1997) and Demsetz and Villalonga (2001) show inside participation in traditional IPOs is a positive function of past performance. We measure growth $(G R O W T H)$ using the percent increase in assets from the year prior to recapitalization. We define performance $(R O A)$ as the accounting percent return on assets in the year prior to the offer. To control for industry performance, we define $I N D \_P / B$ as the industry average price-to-book ratio during the year of the offer. Without wealth constraints, we expect insiders to purchase larger portions of higher performing and faster growing firms. However, with wealth constraints, we do not expect insiders to purchase as large a portion of the firm when the offer size is larger due to firm size, greater growth opportunities, or stronger performance.

Four additional variables control for firm specific and economic variation. To measure the level of current capital in the firm, we define CORE as the core capital ratio the year prior to the offer. EXCH is an indicator variable equal to one if the converted thrift trades on the NYSE, AMEX, or NASDAQ and zero otherwise. INDEX measures the returns on the thrift index in the six weeks prior to the offer and CMT measures the six-week change in interest rates. As economic activity improves we anticipate greater levels of inside participation.

Stock options, stock ownership plans, and management recognition plans may also influence an insider's decision to participate in the offer. The prospectus of a converting thrift typically provides information relating to management's anticipated levels of participation in these plans. We find the mean level of stock options granted to insiders is 9.68\% of total shares. The OTS limits option participation to a maximum of 10\%. In fact, 241 of 261 thrifts (91\%) 
report $10 \%$ anticipated participation. ${ }^{12}$ The mean level of reported employee stock ownership plans (ESOP) and management recognition plans $(M R P)$ is $7.62 \%$ and $3.81 \%$ respectively. The data demonstrate a lack of variability similar to options. The inclusion of this data in our regressions does not affect any of our conclusions, but does reduce the sample size. Therefore, we choose to omit options from the reported tables.

In Table IV, we illustrate that inside participation has a negative relationship with the size of the firm (ASSETS), whether the firm is listed on an exchange $(E X C H)$, the core capital ratio (CORE), and the industry price-to-book ratio (IND_P/B). Wealth constraints limit the proportion of larger firms that insiders can purchase. As shown in equation 5, offers with larger prior conversion value and firms with greater growth opportunities are expected to have larger offer sizes (confirmed later in Table V). The increase in the size of the offer, combined with the wealth constraints of managers, result in lower levels of managerial participation when the industry price-to-book ratio $\left(I N D \_P / B\right)$ and firm capitalization $(C O R E)$ are high. An alternate explanation for the negative coefficient on CORE is that conservative thrift managers who are more likely to oversee higher levels of core capital are less likely to participate in potentially controversial conversions. Finally, firms trading on national exchanges are larger, limiting the ability of managers to purchase as large of a fraction of the firm. Performance measures such as GROWTH and ROA, that were previously found to be positively related to inside participation in IPOs, are not significant in this sample of thrift demutualizations.

${ }^{12}$ Our sample size relating to stock options, employee stock ownership plans and management recognition plans is reduced to 261 based on data availability. Option plans are not voted on until at least six-months following the IPO. 


\section{B. $\quad$ Measuring Asymmetric Information with Unanticipated Inside Purchases}

The results displayed in model 1 of Table IV use information available at the time of the offer to determine the predicted level of inside participation. However, on the day of the offer, investors can use information in the proxy statement to observe the actual number of shares that management purchases. We define unanticipated participation (U_INSIDE) as the difference between the actual participation in the offer and the predicted participation as shown in model 1 of Table IV. This is consistent with the methodology suggested by Aggarwal, Prabhala, and Puri (2002). We posit that unanticipated inside participation signals asymmetric information concerning the future performance of the firm and/or the extent to which insiders manipulated IPO returns through their influence on offer size.

\section{Percentage Price Change at the Time of the IPO}

In model 2 of Table IV, we regress the percentage one-day price change ( $\triangle P R I C E)$ at the time of the IPO on the actual level of inside participation (INSIDE). The INSIDE coefficient is insignificant, indicating that actual participation does not explain initial returns. While Maksimovic and Unal (1993) find inside participation positively related to initial returns, the relationship did not hold in the last three years of their sample (1986 - 1988). Colanuoni (1998) goes further to show the changing character of demutulizations from the 1980's to the 1990's. Both equity capitalization and initial returns increase significantly in the 1990's. Holding proceeds constant, greater pre-conversion equity is expected to increase offer day returns (equation 5).

In model 3, when inside participation is split into anticipated (A_INSIDE) and unanticipated levels (U_INSIDE), both variables are significant but with opposite signs. Anticipated participation is negatively related to the initial return while unanticipated 
participation is positively related. As shown in model 1, unanticipated inside participation has a strong negative correlation with asset size. Due to the omission of assets in model 2, unanticipated inside participation proxies for size; resulting in an inverse relationship with initial returns.

In model 4 of Table IV, we include all of the explanatory variables used to predict inside participation in model 1. SIZE and exchange $(\mathrm{EXCH})$ proxy for issue firm size. Pre-conversion capital (CORE) proxies for the value of the thrift prior to conversion. GROWTH, ROA, and industry price-to-book $\left(I N D \_P / B\right)$ proxy for the individual firm and industry growth opportunities. Consistent with Maksimovic and Unal (1993), we control for current market conditions using the percent change in the equal-weighted thrift index over the previous thirty trading days (INDEX), and the percent change in the ten-year constant maturity Treasury rate over the previous thirty trading days $(C M T)$. The increase in the adjusted $\mathrm{R}^{2}$ indicates that these variables provide information beyond that used to predict inside participation. Greater initial returns are experienced by larger, more profitable firms that demutualize during periods of strong industry performance. INDEX, which reflects changes in current industry conditions, is also positive and highly significant. As hypothesized, higher levels of unanticipated insider purchases are related to significantly higher returns to initial investors. ${ }^{13}$ For every $1 \%$ increase in the unanticipated level of insider purchases the return increases by approximately $0.5 \%$. For the average offer, a \$368,505 increase in inside participation increases IPO investor first-day returns by $\$ 184,252$.

\footnotetext{
${ }^{13}$ We report the results based on ordinary least squares. As stated in Aggarwal, Prabhala, and Puri (2002, p.1438) "non-OLS structural estimates ... are only needed when there is at least one variable in the allocation equation that does not enter into the returns equation." In our analysis all variables from the estimation of inside ownership are also included in the IPO returns equation.
} 
As a whole, models 3 and 4 show that unanticipated participation by insiders is related to higher initial returns at the time of the offer. If anything, anticipated participation is related to lower returns. Thus, the two components clearly provide different information about the thrift and the terms of the offer. Next, we test whether inside participation in a demutualizing firm is more than the traditional signal of management's expectations about the quality of the firm.

\section{Insider Influence on the Offer Size}

As we show in equation 5, a lower offer size increases returns at the time of the offer. Insiders that purchase a larger portion of the offer may enhance initial returns by reducing the offer size. To test our second hypothesis, we use three measures of offer size as dependent variables in our regression analysis. First, we use $P R O C$, defined as the log of proceeds from the offer in thousands. In model 2, offer size is measured using proceeds divided by the book value of equity following the offer; resulting in the offer price-to-book ratio $(P / B) .{ }^{14}$ To further ensure the robustness of our results, we also measure offer size as proceeds scaled by the book value of assets prior to the offer (PROC/ASSETS). This measure controls for the high level of correlation between proceeds and assets, as demonstrated in Table III.

For each model in Table V, we use the independent variables from the estimate of inside participation (model 1 Table IV). As posited in our second hypothesis, we also include U_INSIDE to represent the level of unanticipated inside participation.

All variables except for $U \_I N S I D E$ are positive, indicating that larger thrifts with stronger firm and industry performance generate higher levels of proceeds. U_INSIDE is significant and

\footnotetext{
${ }^{14}$ Prior literature shows that price-to-book ratios are both an important valuation metric and a measure of growth opportunities in the firm. Consistent with Cheng et al. (1989), Rogawski and Simonson (1989), Frieder and Petty (1991), Rose (1991), Palia (1993), Fraser and Kolari (1988), Shawky et al. (1996) and Brewer et al. (2000), price-to-book ratios are expected to be positively related to return-on-assets (ROA), equity-to-assets (CORE), and size (ASSETS).
} 
negative, confirming that when management purchases a larger than anticipated share of the offer, the offer size is lower. Thrift managers use their influence to reduce the level of proceeds in order to obtain higher initial returns on the offer date. Based on the average level of proceeds, for each one percent increase in unanticipated inside participation, there is a 0.016 decrease in the $\log$ of expected proceeds (a reduction of $0.87 \%$ in average proceeds, $\left(\mathrm{e}^{9.91}\right.$ $\left.\mathrm{e}^{9.894}\right)^{*} 1000 / 36,850,470$ ). For the average offer, a $\$ 368,505$ reduction in inside participation results in a $\$ 324,680$ reduction in proceeds.

\section{E. Tests of Long-Term Performance}

Our results lead us to suspect that insiders who purchase a larger than anticipated portion of the offer reduce the size of the offer to enhance first-day returns; however, we have not ruled out the hypothesis that inside participation in an equity offer is a positive signal of long-term performance. Managers could purchase a larger portion of the offer in anticipation of greater future performance and/or growth opportunities. Under this scenario, higher first-day returns are a result of outside investors interpreting inside participation as a signal of future performance.

We use several measures of long-term performance. Specifically, ROA3 is the return-onassets at the end of the third year after the conversion. CHANGE_ROA is the change in the return-on-assets from the year prior to the conversion to three years after the conversion, minus the equivalent change from the thrift industry. As highlighted in Table VI, unanticipated inside participation is not related to future performance as measured by ROA3 and CHANGE_ROA.

We use subsequent stock returns as an additional measure of future performance. We define $A D J \_S T O C K$ as the industry adjusted cumulative three-year return for the stock after the IPO, excluding the initial one-day return. Once again, there is no evidence that unanticipated 
participation is linked to greater long-term performance. ${ }^{15}$ Based on these findings, we reject the alternative hypothesis that greater than anticipated inside participation signals expectation about the future performance of the thrift. We conclude that greater than anticipated inside participation instead signals insiders have incentives to reduce the size of the offer to influence the level of IPO returns.

\section{Conclusions}

Using a sample of 347 conversions of mutual thrifts from 1991 to 2004, we find a 20.8\% average initial return, which is dramatically higher than returns reported by Maksimovic and Unal (1993) for the 1980s. In contrast to the capital impaired thrifts of the 1980's, recent demutulizations of well-capitalized thrifts have dramatically higher initial returns.

We use demutualizations in the thrift industry to investigate the role that company insiders play in the initial public offer process. Previous studies propose that inside participation in a demutualizing thrift is a signal of firm value. We test whether inside participation in the offer is positively related to returns on the first day of the IPO. We demonstrate that it is the unanticipated portion of inside purchases that signals greater first-day return performance. Returns are higher when insiders purchase a larger than anticipated portion of the offer.

${ }^{15}$ In addition to the subsequent performance measures discussed above, we use net interest margin and growth in assets. First, we use the net interest margin defined both as the net interest margin at the end of the third year after the conversion and as the industry adjusted change in net interest margin after three years. Maksimovic and Unal (1993) evaluate the impact of demutualization on the subsequent growth of the firm. We use the growth in assets in the three years subsequent to the offer. In results not shown, we do not find a statistically significant relationship between the level of unanticipated inside participation in the offer and future net interest margin or firm growth. 
Unanticipated levels of managerial participation are negatively related to the size of the offer. In a thrift demutualization, the lower the offer size, the greater the expected return. Initial shareholders invest the proceeds to receive the full value of the firm, including the pre-IPO market value of the thrift and the present value of growth opportunities related to the new capital. We find no evidence that inside participation is related to the future performance of the firm. Our study demonstrates that thrift managers are not signaling future performance, but rather the extent that the offer size has been reduced to enhance first-day IPO returns. It should be noted that greater inside participation and its influence on proceeds are not at odds with the interests of new investors. The interests of insiders are aligned with the initial shareholders who invest in the IPO. 


\section{REFERENCES}

Aboody, David, and Ron Kasznik. (2000). "CEO Stock Option Awards and the Timing of Corporate Voluntary Disclosures.” Journal of Accounting and Economics 29, 73-100.

Aggarwal, Reena, Nagpurnanand Prabhala, and Manju Puri. (2002). "Institutional Allocation in Initial Public Offerings: Empirical Evidence.” Journal of Finance 62, 1421-1442.

Allen, Franklin, and Gerald Faulhaber. (1989). "Signaling by Underpricing in the IPO Market." Journal of Financial Economics 23, 303-323.

Alli, Kasim, Jot Yau, and Kenneth Yung. (1994). "The Underpricing of IPOs of Financial Institutions.” Journal of Business Finance and Accounting 21, 1023-1030.

Ang, James, and James Brau. (2003). "Concealing and Confounding Advers Signals: Inside Wealth-Maximizing Behavior in the IPO process.” Journal of Financial Economics 67, 149-172.

Barro, Robert. (1977). "Unanticipated Money Growth and Unemployment in the United States.” American Economic Review 67, 101-115.

Barth, James, Dan Brumbaugh, and Allan Kleidon. (1994). "Windfall Gains in Mutual-to-Stock Conversions of Thrift Institutions.” Challenge, July/August, 43-49.

Beatty, Randolph, and Jay Ritter. (1986). "Investment Banking, Reputation, and the Underpricing of Initial Public Offerings.” Journal of Financial Economics 15, 213-232.

Benveniste, Lawrence, and Paul Spindt. (1989). "How Investment Bankers Determine the Offer Price and Allocation of New Issues.” Journal of Financial Economics 24, 343-361.

Boyle, Glenn, Richard Carter, and Roger Stover. (1998). "Extraordinary Antitakeover Provisions and Insider Ownership Structure; The Case of Converting Savings and Loans.” Journal of Financial and Quantitative Analysis 33, 291-304.

Brewer III, Elijah, William Jackson III, Julapa Jagtiani, and Thong Nguyen. (2000). "The Price of Bank Mergers in the 1990s.” Economic Perspectives 24, 2-23.

Chalmers, John, Larry Dann, and Jarrad Harford. (2002). "Managerial Opportunism? Evidence from Directors’ and Officers’ Insurance Purchases.” Journal of Finance 62, 609-636.

Chemmanur, Thomas. (1993). "The Pricing of Initial Public Offerings: A dynamic Model with Information Production.” Journal of Finance 48, 285-305.

Cheng, David, Benton Gup, and Larry Wall. (1989). "Financial Determinants of Bank Takeovers.” Journal of Money Credit and Banking 21, 524-536. 
Clarke, Jonathon, Craig Dunbar, and Kathleen Kahle. (2001). "Long-Run Performance and Insider Trading in Completed and Cancelled Seasoned Equity Offerings.” Journal of Financial and Quantitative Analysis 36, 415-430.

Colantuoni, Joseph A. (1998). "Mutual-to-Stock Conversions: Problems with the Pricing of Initital Public Offerings.” FDIC Banking Review 11, 1-9.

Cox, Steven, and Dianne Roden. (1999). "Initial Public Offerings by Mutual Thrifts: The Regulatory Impact.” Journal of Economics and Finance 23, 113-122.

Demsetz, Harold and Belen Villalonga. (2001). "Ownership Structure and Corporate Performance.” UCLA working paper.

Drake, Philip and Michael Vetsuypens. (1993). "IPO Underpricing and Insurance Against Legal Liability." Financial Management 22, 64-73.

Dunham, Constance. (1985). "Mutual-to-Stock Conversions By Thrifts: Implications for Soundness.” New England Economic Review January/February, 31-45.

Fenn, George, and Nellie Liang. (2001). "Corporate Payout Policy and Managerial Stock Incentives.” Journal of Financial Economics 60, 45-72.

Field, Laura, and Jonathan Karpoff. (2002). “Takeover Defenses of IPO Firms.” Journal of Finance 57, 1857-1891.

Fraser, Donald, and James Kolari. (1988). “Pricing Small Bank Acquisitions.” Journal of Retail Banking 10, 23-28.

Frieder, Larry, and Phillip Petty. (1991). "Determinants of Bank Acquisition Premiums: Issues and Evidence.” Contemporary Policy Issue 9, 13-24.

Garfinkel, Jon. (1993). "IPO Underpricing, Insider Selling and Subsequent Equity Offerings: Is Underpricing a Signal of Quality?” Financial Management 22, 74-83.

Giammarino, Ronald, Robert Heinkel, and Burton Hillifield. (1994). “Corporate Financing Decisions and Anonymous Trading. Journal of Financial and Quantitative Analysis 29, 351-377.

Kahle, Kathleen. (2000). "Insider Trading and Long-Run Performance of New Security Issues.” Journal of Corporate Finance 6, 25-53.

Karpoff, Jonathan, and Daniel Lee. (1991). "Inside Trading before New Issue Announcements.” Financial Manangement 20, 18-26.

Kroszner, Randall, and Philip Strahan. (1996). "Regulatory Incentives and the Thrift Crisis: Dividends, Mutual-to-Stock Conversions, and Financial Distress.” Journal of Finance 51, 12851319. 
Lambert, Richard, William Lanen, and David Larcker. (1989). "Executive Stock Option Plans and Corporate Dividend Policy.” Journal of Financial and Quantitative Analysis 24, 409-425.

Lee, Inmoo. (1997). “Do Firms Knowingly Sell Overvalued Equity?” Journal of Finance 52, 1439-1466.

Loderer, Claudio and Kenneth Martin. (1997). "Executive Stock Ownership and Performance: Tracking Faint Traces.” Journal of Financial Economics 45, 223-256.

Lowry, Michelle, and Susan Shu. (2002). "Litigation Risk and IPO Underpricing.” Journal of Financial Economics 65, 309-355.

Luse, Eric and John Gorman. (2005). "Research \& Analysis: Conversions - A Review of 2004 and the Outlook for 2005”. SNLi. 11, March 2005.

Maksimovic, Vojislav, and Haluk Unal. (1993). "Issue Size Choice and "Underpricing” in Thrift Mutual-to-Stock Conversions.” Journal of Finance 48, 1659-1692.

Masulis, Ronald. (1987). "Changes in Ownership Structure: Conversions of Mutual Savings and Loans to Stock Charter.” Journal of Financial Economics 18, 29-59.

Meredith, Robyn. (1994). "OTS Proposal Would Curb Windfalls For Managers in Mutual Conversions Series.” American Banker 159, No. 69.

Palia, Darius. (1993). "The Managerial, Regulatory, and Financial Determinants of Bank Merger Premiums.” Journal of Industrial Economics 41, 91-102.

Rhoades, Stephen. (1987). "Determinants of Premiums Paid in Bank Acquisitions.” Atlantic Economic Journal 15, 20-30.

Rock, Kevin. (1986). "Why New Issues are Underpriced.” Journal of Financial Economics 15, 187-212.

Rogawski, Robert, and Donald Simonson (1989). "Bank Merger Pricing Premiums and Interstate Bidding.” in Bank Mergers: Current Issues and Perspectives, Benton E. Gup (ed.), 87-106.

Rose, Peter. (1991). "Bidding Theory and Bank Merger Premiums: The Impact of Structural and Regulatory Factors.” Review of Business and Economic Research 26, 22-40.

Rudd, Jon. (1993). “Underwriter Price Support and the IPO “Underpricing” Puzzle.” Journal of Financial Economics 34, 135-151.

Seyhun, Nejat. (1986). “Insiders' Profits, Costs of Trading, and Market Efficiency.” Journal of Financial Economics 16, 189-212. 
Shawky, Hanny, Tobias Kilb, and Carsten Staas. (1996). "Determinants of Bank Merger Premiums.” Journal of Economics and Finance 20, 117-131.

Smith, Dwight, and James Underwood. (1997). Mutual Savings Associations and Conversion to Stock Form. Office of Thrift Supervision.

Teoh, Siew Hong, Ivo Welch, and T. J. Wong. (1998). "Earnings Management and the LongRun Market Performance of Initial Public Offerings.” Journal of Finance 53, 1935-1974.

Unal, Haluk. (1997). "Regulatory Misconceptions in Pricing Thrift Conversions: A Closer Look at the Appraisal Process.” Journal of Financial Services Research 11, 239-254.

Watterson, Bruce and Donald Laufenberg. (1990). "S\&Ls Need Strategy to Go with New Capital Series.” American Banker 155, No. 173.

Welch, Ivo. (1989). "Seasoned Offerings, Imitation Costs, and the Underpricing of Initial Public Offerings.” Journal of Finance 44, 421-449.

Yermack, David. (1997). "Good Timing: CEO Stock Option Awards and Company New Announcements.” Journal of Finance 52, 449-476. 
Table 1

Frequency of Conversions by Year

\begin{tabular}{cc}
\hline Year & Frequency \\
\hline 1991 & 2 \\
1992 & 19 \\
1993 & 40 \\
1994 & 55 \\
1995 & 61 \\
1996 & 54 \\
1997 & 29 \\
1998 & 35 \\
1999 & 18 \\
2000 & 10 \\
2001 & 9 \\
2002 & 6 \\
2003 & 6 \\
2004 & 3 \\
& \\
Total & $\mathbf{3 4 7}$ \\
\hline
\end{tabular}




\section{Table II \\ Summary Statistics of Selected Variables}

ASSETS is calculated as the log of the firm's total assets in thousands from the year prior to the demutualization. $E X C H$ is equal to one if traded on the NYSE, AMEX, or NASDAQ - zero otherwise. CORE is the core capital ratio as a percentage equal to core capital divided by risk-adjusted assets from the year prior to the offer. GROWTH is the percent increase in assets from the year prior to the conversion. $R O A$ is the percent return-on-assets in the year prior to the offer. IND_P/B is the industry average price to book ratio at the year of the demutualization. INSIDE is the percent of the shares purchased by officers and directors. $\triangle P R I C E$ is the percent price change at the IPO. PROC is defined as the $\log$ of proceeds from the offer in thousands. $P / B$ is the ratio of the offer price-to-book value at the time of the offer. PROC/ASSETS is the ratio proceeds to the assets in the year prior to demutualization.

\begin{tabular}{|c|c|c|c|c|}
\hline Variable & $\begin{array}{c}\text { Mean } \\
(\mathrm{n}=347)\end{array}$ & $\begin{array}{l}\text { Standard } \\
\text { Deviation }\end{array}$ & Minimum* & Maximum* $^{*}$ \\
\hline Total Assets from the Year Prior to Conversion & $\$ 285,980,270$ & $\$ 337,091,290$ & $\$ 31,107,000$ & $\$ 1,297,226,000$ \\
\hline ASSETS & 11.99 & 1.06 & 10.35 & 14.08 \\
\hline EXCH & $77.52 \%$ & $41.80 \%$ & $0 \%$ & $100 \%$ \\
\hline CORE & $18.70 \%$ & $7.67 \%$ & $8.19 \%$ & $36.96 \%$ \\
\hline GROWTH & $5.35 \%$ & $8.40 \%$ & $-6.71 \%$ & $28.74 \%$ \\
\hline ROA & $0.69 \%$ & $0.43 \%$ & $-0.24 \%$ & $1.49 \%$ \\
\hline$I N D \_P / B$ & $97.70 \%$ & $21.77 \%$ & $46.00 \%$ & $140.30 \%$ \\
\hline INSIDE & $8.12 \%$ & $5.99 \%$ & $1.20 \%$ & $24.30 \%$ \\
\hline$\triangle P R I C E$ & $20.78 \%$ & $15.69 \%$ & $-2.50 \%$ & $55.00 \%$ \\
\hline Proceeds from the Offer & $\$ 36,850,470$ & $\$ 44,400,710$ & $\$ 3,042,000$ & $\$ 171,925,000$ \\
\hline PROC & 9.91 & 1.07 & 7.78 & 11.85 \\
\hline$P / B$ & $66.62 \%$ & $8.95 \%$ & $44.99 \%$ & $81.60 \%$ \\
\hline PROC/ASSETS & $14.12 \%$ & $6.29 \%$ & $2.88 \%$ & $26.83 \%$ \\
\hline
\end{tabular}

* After Winsorizing 


\section{Table III \\ Correlation Matrix of Regression Variables}

ASSETS is calculated as the log of the firm's total assets in thousands from the year prior to the demutualization. $E X C H$ is equal to one if traded on the NYSE, AMEX, or NASDAQ - zero otherwise. CORE is the core capital ratio as a percentage equal to core capital divided by risk-adjusted assets from the year prior to the offer. GROWTH is the percent increase in assets from the year prior to the conversion. $R O A$ is the percent return-on-assets in the year prior to the offer. IND_P/B is the industry average price to book ratio at the year of the demutualization. INSIDE is the percent of the shares purchased by officers and directors. $\triangle P R I C E$ is the percent price change at the IPO. PROC is defined as the log of proceeds in thousands from the offer. $P / B$ is the ratio of the offer price-to-book value at the time of the offer. PROC/ASSETS is the ratio proceeds to the assets in the year prior to demutualization. P-values are given in parentheses.

\begin{tabular}{|c|c|c|c|c|c|c|c|c|c|c|}
\hline & ASSETS & EXCH & CORE & GROWTH & $R O A$ & IND_P/B & INSIDE & $\triangle P R I C E$ & PROC & $P / B$ \\
\hline ASSETS & 1 & & & & & & & & & \\
\hline EXCH & $\begin{array}{c}0.566 \\
(0.000)\end{array}$ & 1 & & & & & & & & \\
\hline CORE & $\begin{array}{c}-0.310 \\
(0.000)\end{array}$ & $\begin{array}{c}-0.038 \\
(0.483)\end{array}$ & 1 & & & & & & & \\
\hline GROWTH & $\begin{array}{c}0.061 \\
(0.257)\end{array}$ & $\begin{array}{c}0.006 \\
(0.090)\end{array}$ & $\begin{array}{c}0.038 \\
(0.479)\end{array}$ & 1 & & & & & & \\
\hline$R O A$ & $\begin{array}{c}-0.061 \\
(0.257)\end{array}$ & $\begin{array}{c}0.179 \\
(0.001)\end{array}$ & $\begin{array}{c}0.329 \\
(0.000)\end{array}$ & $\begin{array}{c}0.096 \\
(0.075)\end{array}$ & 1 & & & & & \\
\hline$I N D \_P / B$ & $\begin{array}{c}-0.162 \\
(0.003)\end{array}$ & $\begin{array}{c}-0.224 \\
(0.000)\end{array}$ & $\begin{array}{c}0.154 \\
(0.004)\end{array}$ & $\begin{array}{c}0.164 \\
(0.002)\end{array}$ & $\begin{array}{c}-0.042 \\
(0.437)\end{array}$ & 1 & & & & \\
\hline INSIDE & $\begin{array}{c}-0.609 \\
(0.000)\end{array}$ & $\begin{array}{l}-0.377 \\
(0.000)\end{array}$ & $\begin{array}{l}-0.051 \\
(0.343)\end{array}$ & $\begin{array}{c}-0.092 \\
(0.088)\end{array}$ & $\begin{array}{c}-0.059 \\
(0.275)\end{array}$ & $\begin{array}{c}-0.172 \\
(0.001)\end{array}$ & 1 & & & \\
\hline$\triangle P R I C E$ & $\begin{array}{c}0.139 \\
(0.009)\end{array}$ & $\begin{array}{c}0.117 \\
(0.029)\end{array}$ & $\begin{array}{c}0.051 \\
(0.340)\end{array}$ & $\begin{array}{c}0.076 \\
(0.159)\end{array}$ & $\begin{array}{c}0.186 \\
(0.000)\end{array}$ & $\begin{array}{c}0.176 \\
(0.001)\end{array}$ & $\begin{array}{c}-0.031 \\
(0.569)\end{array}$ & 1 & & \\
\hline PROC & $\begin{array}{c}0.879 \\
(0.000)\end{array}$ & $\begin{array}{c}0.569 \\
(0.000)\end{array}$ & $\begin{array}{c}-0.004 \\
(0.943)\end{array}$ & $\begin{array}{c}0.128 \\
(0.017)\end{array}$ & $\begin{array}{c}0.121 \\
(0.024)\end{array}$ & $\begin{array}{c}0.078 \\
(0.145)\end{array}$ & $\begin{array}{c}-0.618 \\
(0.000)\end{array}$ & $\begin{array}{c}0.221 \\
(0.000)\end{array}$ & 1 & \\
\hline$P / B$ & $\begin{array}{c}-0.010 \\
(0.850)\end{array}$ & $\begin{array}{c}0.047 \\
(0.379)\end{array}$ & $\begin{array}{c}0.143 \\
(0.007)\end{array}$ & $\begin{array}{c}0.197 \\
(0.000)\end{array}$ & $\begin{array}{c}0.177 \\
(0.001)\end{array}$ & $\begin{array}{c}0.564 \\
(0.000)\end{array}$ & $\begin{array}{c}-0.357 \\
(0.000)\end{array}$ & $\begin{array}{c}0.189 \\
(0.000)\end{array}$ & $\begin{array}{c}0.319 \\
(0.000)\end{array}$ & 1 \\
\hline PROC/ASSETS & $\begin{array}{c}-0.153 \\
(0.004)\end{array}$ & $\begin{array}{c}0.055 \\
(0.311)\end{array}$ & $\begin{array}{c}0.637 \\
(0.000)\end{array}$ & $\begin{array}{c}0.082 \\
(0.129)\end{array}$ & $\begin{array}{c}0.374 \\
(0.000)\end{array}$ & $\begin{array}{c}0.490 \\
(0.000)\end{array}$ & $\begin{array}{c}-0.275 \\
(0.000)\end{array}$ & $\begin{array}{c}0.244 \\
(0.001)\end{array}$ & $\begin{array}{c}0.297 \\
(0.000)\end{array}$ & $\begin{array}{r}0.664 \\
(0.000)\end{array}$ \\
\hline
\end{tabular}




\section{Table IV \\ Ordinary Least Squares Regression of Inside Participation and Percentage Price Change at the Time of the IPO}

The dependent variable, INSIDE, in model 1 is the percent of the shares purchased by officers and directors. In models 2, 3, and 4, the dependent variable, $\triangle P R I C E$, is the percentage price change at the IPO. ASSETS is calculated as the log of the firm's total assets in thousands from the year prior to the demutualization. EXCH is equal to one if traded on the NYSE, AMEX, or NASDAQ - zero otherwise. CORE is the core capital ratio as a percentage equal to core capital divided by risk-adjusted assets from the year prior to the offer. GROWTH is the percent increase in assets from the year prior to the conversion. $R O A$ is the percent return-on-assets in the year prior to the offer. $I N D \_P / B$ is the industry average price to book ratio at the year of the demutualization. INDEX is the return on the thrift index in the six week period preceding the offer. $C M T$ is the six week change in the ten-year Constant Maturity Treasury yield. INSIDE is the percent of the shares purchased by officers and directors. A_INSIDE is the predicted value of inside participation using the model shown in model 1. U_INSIDE is the error term from model 1. t-values appear in parentheses below coefficient estimates. ${ }^{*},{ }^{* *}$, and ${ }^{* * *}$ denote significance at the .1, .05, and .01 levels respectively for two-tailed tests.

\begin{tabular}{|c|c|c|c|c|}
\hline \multirow{3}{*}{$\begin{array}{c}\text { Independent } \\
\text { Variables }\end{array}$} & \multicolumn{4}{|c|}{ Dependent Variables } \\
\hline & \multirow{2}{*}{$\begin{array}{l}\text { INSIDE } \\
\text { Model } 1 \\
\end{array}$} & \multicolumn{3}{|c|}{$\Delta$ PRICE } \\
\hline & & Model 2 & Model 3 & Model 4 \\
\hline Intercept & $\begin{array}{l}54.186 \\
(13.21)^{* * *}\end{array}$ & $\begin{array}{l}21.436 \\
(15.08)^{* * *}\end{array}$ & $\begin{array}{l}29.248 \\
(14.81)^{* * * *}\end{array}$ & $\begin{array}{l}-56.189 \\
(-5.17)^{* * *}\end{array}$ \\
\hline ASSETS & $\begin{array}{c}-2.923 \\
(-9.18)^{* * *}\end{array}$ & & & $\begin{array}{l}3.291 \\
(3.90)^{* * *}\end{array}$ \\
\hline $\mathrm{EXCH}$ & $\begin{array}{l}-2.057 \\
(-2.60)^{* * *}\end{array}$ & & & $\begin{array}{l}1.995 \\
(0.95)\end{array}$ \\
\hline CORE & $\begin{array}{l}-0.135 \\
(-3.54)^{* * *}\end{array}$ & & & $\begin{array}{c}0.114 \\
(1.13)\end{array}$ \\
\hline GROWTH & $\begin{array}{l}-0.007 \\
(-0.23)\end{array}$ & & & $\begin{array}{l}-0.007 \\
(-0.08)\end{array}$ \\
\hline$R O A$ & $\begin{array}{l}-0.195 \\
(-0.30)\end{array}$ & & & $\begin{array}{l}6.377 \\
(3.70)^{* * *}\end{array}$ \\
\hline$I N D \_P / B$ & $\begin{array}{l}-0.071 \\
(-5.60)^{* * *}\end{array}$ & & & $\begin{array}{l}0.205 \\
(6.13)^{* * *}\end{array}$ \\
\hline INDEX & $\begin{array}{l}0.043 \\
(0.49)\end{array}$ & & & $\begin{array}{l}2.357 \\
(9.99)^{* * *}\end{array}$ \\
\hline CMT & $\begin{array}{l}0.857 \\
(1.02)\end{array}$ & & & $\begin{array}{l}-1.833 \\
(-0.82)\end{array}$ \\
\hline INSIDE & & $\begin{array}{l}-0.080 \\
(-0.57)\end{array}$ & & \\
\hline A_INSIDE & & & $\begin{array}{l}-1.043 \\
(-4.70)^{* * *}\end{array}$ & \\
\hline U_INSIDE & & & $\begin{array}{c}0.491 \\
(2.87)^{* * *}\end{array}$ & $\begin{array}{c}0.489 \\
(3.39)^{* * *}\end{array}$ \\
\hline Observations & 347 & 347 & 347 & 347 \\
\hline Adjusted $\mathrm{R}^{2}$ & .360 & -0.002 & 0.076 & .345 \\
\hline$p$-value of $F$-test & $<.0001$ & 0.569 & $<.0001$ & $<.0001$ \\
\hline
\end{tabular}




\section{Table V \\ Ordinary Least Square Regression of Measures of the Level of Proceeds}

$P R O C$ is defined as the log of proceeds from the offer in thousands. $P / B$ is the offer price to book value at the time of the offer. PROC/ASSETS is defined as the proceeds of the offer divided by the assets in the year prior to demutualization. ASSETS is calculated as the log of the firm's total assets in thousands from the year prior to the demutualization. EXCH is equal to one if traded on the NYSE, AMEX, or NASDAQ - zero otherwise. CORE is the core capital ratio as a percentage equal to core capital divided by risk-adjusted assets from the year prior to the offer. $G R O W T H$ is the percent increase in assets from the year prior to the conversion. $R O A$ is the percent return-on-assets in the year prior to the offer. $I N D \_P / B$ is the industry average price to book ratio at the year of the demutualization. U_INSIDE is the error term using the model shown in Table IV. t-values appear in parentheses below coefficient estimates. ${ }^{*}, * *$, and ${ }^{* * *}$ denote significance at the $.1, .05$, and .01 levels respectively for two-tailed tests.

\begin{tabular}{|c|c|c|c|}
\hline \multirow{2}{*}{$\begin{array}{c}\text { Independent } \\
\text { Variables }\end{array}$} & \multicolumn{3}{|c|}{ Dependent Variable } \\
\hline & PROC & $\mathbf{P} / \mathbf{B}$ & PROC/ASSETS \\
\hline Intercept & $\begin{array}{c}-3.465 \\
(-12.83)^{* * *}\end{array}$ & $\begin{array}{c}36.549 \\
(6.46)^{* * *}\end{array}$ & $\begin{array}{c}-11.671 \\
(-3.69)^{* * *}\end{array}$ \\
\hline ASSETS & $\begin{array}{c}0.954 \\
(44.51)^{* * *}\end{array}$ & $\begin{array}{l}0.088 \\
(0.20)\end{array}$ & $\begin{array}{l}0.136 \\
(0.54)\end{array}$ \\
\hline $\mathrm{EXCH}$ & $\begin{array}{c}0.180 \\
(3.37)^{* * *}\end{array}$ & $\begin{array}{c}3.070 \\
(2.75)^{* * *}\end{array}$ & $\begin{array}{c}1.904 \\
(3.05)^{* * *}\end{array}$ \\
\hline CORE & $\begin{array}{c}0.032 \\
(12.35)^{* * *}\end{array}$ & $\begin{array}{l}0.003 \\
(0.05)\end{array}$ & $\begin{array}{c}0.419 \\
(13.93)^{* * *}\end{array}$ \\
\hline GROWTH & $\begin{array}{l}0.002 \\
(0.98)\end{array}$ & $\begin{array}{c}0.087 \\
(1.96)^{*}\end{array}$ & $\begin{array}{l}-0.026 \\
(-1.06)\end{array}$ \\
\hline$R O A$ & $\begin{array}{c}0.242 \\
(5.52)^{* * *}\end{array}$ & $\begin{array}{c}3.451 \\
(3.77)^{* * *}\end{array}$ & $\begin{array}{c}2.999 \\
(5.85)^{* * *}\end{array}$ \\
\hline$I N D \_P / B$ & $\begin{array}{c}0.010 \\
(12.43)^{* * *}\end{array}$ & $\begin{array}{c}0.243 \\
(13.76)^{* * *}\end{array}$ & $\begin{array}{c}0.132 \\
(13.40)^{* * *}\end{array}$ \\
\hline U_INSIDE & $\begin{array}{l}-0.016 \\
(-4.34)^{* * *}\end{array}$ & $\begin{array}{l}-0.427 \\
(-5.55)^{* * *}\end{array}$ & $\begin{array}{c}-0.170 \\
(-3.96)^{* * *}\end{array}$ \\
\hline Observations & 347 & 347 & 347 \\
\hline Adjusted $\mathrm{R}^{2}$ & .908 & .426 & .637 \\
\hline$p$-value of $F$-test & $<.0001$ & $<.0001$ & $<.0001$ \\
\hline
\end{tabular}




\section{Table VI}

\section{Ordinary Least Square Regression of Subsequent ROA and Stock Performance}

$R O A 3$ is the return-on-assets at the end of the third year after the conversion. CHANGE_ROA is the ratio of the return-on-assets three years after the conversion divided by the return-on-assets from the year before the conversion, minus the equivalent ratio from the thrift industry. ADJ_STOCK is the industry adjusted cumulative three-year return for the stock after the IPO. ASSETS is calculated as the log of the firm's total assets in thousands from the year prior to the demutualization. EXCH is equal to one if traded on the NYSE, AMEX, or NASDAQ - zero otherwise. CORE is the core capital ratio as a percentage equal to core capital divided by risk-adjusted assets from the year prior to the offer. GROWTH is the percent increase in assets from the year prior to the conversion. ROA is the percent return-on-assets in the year prior to the offer. $I N D \_P / B$ is the industry average price to book ratio at the year of the demutualization. INDEX is the return on the thrift index in the six week period preceding the offer. CMT is the six week change in the ten-year Constant Maturity Treasury yield. U_INSIDE is the error term using the model shown in Table IV. t-values appear in parentheses below coefficient estimates. ${ }^{*},{ }^{* *}$, and ${ }^{* * *}$ denote significance at the $.1, .05$, and .01 levels respectively for two-tailed tests.

\begin{tabular}{|c|c|c|c|}
\hline \multirow{2}{*}{$\begin{array}{c}\text { Independent } \\
\text { Variables } \\
\end{array}$} & \multicolumn{3}{|c|}{ Dependent Variable } \\
\hline & ROA3 & CHANGE_ROA & ADJ_STOCK \\
\hline Intercept & $\begin{array}{l}-0.407 \\
(-1.05)\end{array}$ & $\begin{array}{l}-0.993 \\
(-1.44)\end{array}$ & $\begin{array}{l}-1.365 \\
(-1.54)\end{array}$ \\
\hline ASSETS & $\begin{array}{l}0.068 \\
(2.28)^{* *}\end{array}$ & $\begin{array}{l}0.135 \\
(2.56)^{* *}\end{array}$ & $\begin{array}{c}0.206 \\
(3.27)^{* * *}\end{array}$ \\
\hline$E X C H$ & $\begin{array}{l}0.098 \\
(1.31)\end{array}$ & $\begin{array}{l}0.064 \\
(0.48)\end{array}$ & $\begin{array}{l}0.091 \\
(0.32)\end{array}$ \\
\hline CORE & $\begin{array}{c}0.006 \\
(1.80)^{*}\end{array}$ & $\begin{array}{l}0.004 \\
(0.66)\end{array}$ & $\begin{array}{l}-0.016 \\
(-1.94)^{*}\end{array}$ \\
\hline GROWTH & $\begin{array}{l}0.003 \\
(1.13)\end{array}$ & $\begin{array}{l}-0.007 \\
(-1.40)\end{array}$ & $\begin{array}{l}-0.007 \\
(-1.17)\end{array}$ \\
\hline$R O A$ & $\begin{array}{l}0.229 \\
(3.77)^{* * *}\end{array}$ & $\begin{array}{l}-1.043 \\
(-9.63)^{* * *}\end{array}$ & $\begin{array}{l}-0.213 \\
(-1.53)\end{array}$ \\
\hline$I N D \_P / B$ & $\begin{array}{c}-0.0002 \\
(-0.17)\end{array}$ & $\begin{array}{l}0.002 \\
(0.96)\end{array}$ & $\begin{array}{l}-0.004 \\
(-1.51)\end{array}$ \\
\hline INDEX & $\begin{array}{l}0.004 \\
(0.46)\end{array}$ & $\begin{array}{l}0.001 \\
(0.08)\end{array}$ & $\begin{array}{l}-0.018 \\
(-0.93)\end{array}$ \\
\hline CMT & $\begin{array}{c}0.0004 \\
(0.01)\end{array}$ & $\begin{array}{l}0.132 \\
(0.96)\end{array}$ & $\begin{array}{l}-0.105 \\
(-0.60)\end{array}$ \\
\hline U_INSIDE & $\begin{array}{l}-0.003 \\
(-0.54)\end{array}$ & $\begin{array}{l}-0.010 \\
(-1.15)\end{array}$ & $\begin{array}{l}0.013 \\
(1.03)\end{array}$ \\
\hline Observations & 247 & 247 & 219 \\
\hline Adjusted $\mathrm{R}^{2}$ & 0.103 & 0.337 & 0.144 \\
\hline$p$-value of $F$-test & $<.0001$ & $<.0001$ & $<.0001$ \\
\hline
\end{tabular}

